\title{
Case Report: Myiasis as a rare complication of invasive ductal
}

\section{carcinoma [version 1; peer review: 1 approved, 1 approved}

\section{with reservations]}

\author{
Muhammad Khurram Zia1', Syeda Ifra Asad², Hafiz Abdul Wase ${ }^{3}$, Osama Salam², \\ Syed Zawahir Hassan (D) 4, Muhammad Musab², Syed Mumtaz Ali Naqvi², \\ Hafiz Muhammad Furqan Izhar ${ }^{1}$ \\ ${ }^{1}$ Liaqat College of Medicine, Karachi, Pakistan \\ ${ }^{2}$ Dow University of Health Sciences, Karachi, Sindh, Pakistan \\ ${ }^{3}$ Karachi Medical and Dental College, Karachi, Pakistan \\ ${ }^{4}$ Park Plaza Hospital, Houston, Texas, USA
}

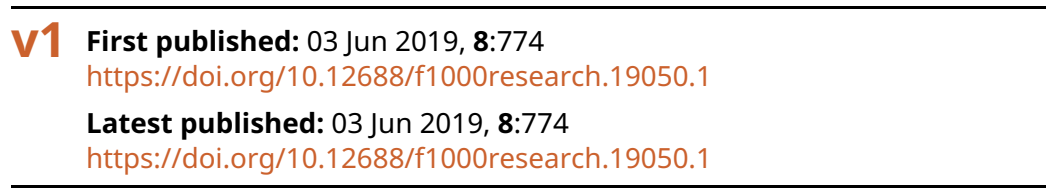

\section{Abstract}

Invasive ductal carcinoma (IDC) is the most common subtype of breast tumor. There were many cases reported about the treatment and adjuvant therapies. The simultaneously occurrence of breast carcinoma with cutaneous myiasis is, to our knowledge, a unique presentation. A 50-year-old female known case of breast cancer presented to the surgical department at Ziauddin Hospital Karachi with complaints of pain, redness, blackening, and a foul smelling, discharging wound on her left breast. The wound was debrided thoroughly with povidone-iodine and about 52 maggots were removed, which were identified as Chrysomya bezziana. The patient was hospitalized and received amoxicillin and ivermectin according to protocol. This case report is pertinent to public health professionals and oncologists in the view of the social impact of myiasis.

Keywords

Myiasis, Parasitic Infection, Invasive ductal carcinoma

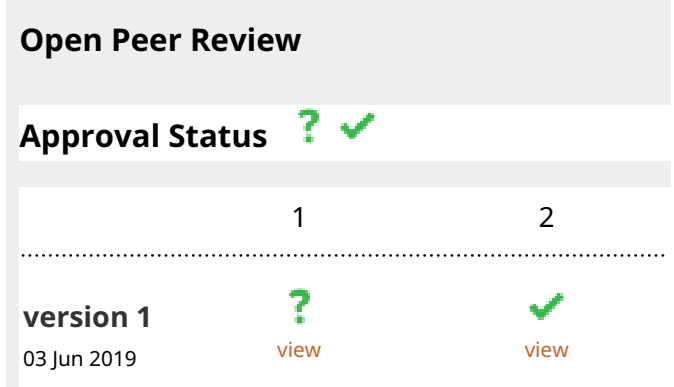

1. Stefano Veraldi, University of Milan, Milan, Italy

2. Yunjiang Liu (DD, Fourth Hospital of Hebei Medical University, Shijiazhuang, China Any reports and responses or comments on the article can be found at the end of the article. 
Corresponding author: Syed Zawahir Hassan (drzawahir@gmail.com)

Author roles: Zia MK: Writing - Original Draft Preparation; Asad SI: Writing - Original Draft Preparation; Wase HA: Writing - Original Draft Preparation; Salam O: Conceptualization; Hassan SZ: Conceptualization; Musab M: Writing - Review \& Editing; Ali Naqvi SM: Writing - Review \& Editing; Izhar HMF: Project Administration

Competing interests: No competing interests were disclosed.

Grant information: The author(s) declared that no grants were involved in supporting this work.

Copyright: @ 2019 Zia MK et al. This is an open access article distributed under the terms of the Creative Commons Attribution License, which permits unrestricted use, distribution, and reproduction in any medium, provided the original work is properly cited.

How to cite this article: Zia MK, Asad SI, Wase HA et al. Case Report: Myiasis as a rare complication of invasive ductal carcinoma [version 1; peer review: 1 approved, 1 approved with reservations] F1000Research 2019, 8:774

https://doi.org/10.12688/f1000research.19050.1

First published: 03 Jun 2019, 8:774 https://doi.org/10.12688/f1000research.19050.1 


\section{Introduction}

Breast carcinoma is the second-leading cause of cancer-related mortality in women. Invasive ductal carcinoma is most common histological subtype of breast carcinoma ${ }^{1}$. Myiasis is the dipterous larvae infestation of human or animal tissues. It is typically associated with inadequate personal hygiene due to lack of awareness among individuals in tropical and subtropical countries. Dipterous larvae in the feeding life cycle of may be found in living or dead tissues ${ }^{2-5}$. Many treatment options are available for invasive ductal carcinoma found with gangrenous tissues, with radiotherapy considered highly commendable in order to reduce disease recurrence ${ }^{6,7}$.

\section{Case report}

A 50-year-old female presented to the surgical department at Ziauddin Hospital Karachi with complaints of pain, redness, blackening, and a foul smelling and discharging wound in the left breast. She had a history of invasive ductal carcinoma which was diagnosed 2.5 years previously but could not get treatment for financial reasons. (Figure 1). On examination, the patient looked weak and lethargic. She had a fever of $101^{\circ} \mathrm{F}\left(38.3^{\circ} \mathrm{C}\right)$ The majority of the breast was hard in consistency with a purulent sanguineous discharging ulcer, which was foul smelling due to superimposed bacterial infection. The surrounding skin was gangrenous and numerous grayish maggots were seen crawling around.

The wound was debrided thoroughly with povidone-iodine in the emergency room and about 52 maggots were removed carefully, preserved and sent for entomological review which were identified as Chrysomya bezziana. The maggots were 15 to $20 \mathrm{~mm}$ long, whitish or greyish in color without body process. There is an enlargement of anterior spiracle and darkened portion of trunks, posterior spiracle extended three or four abdominal segments (Figure 2 and Figure 3). The patient was given widespectrum antibiotic amoxicillin $1 \mathrm{~g}$ twice a day for 7 days and Ivermectin $6 \mathrm{~g}$ twice a day for 1 day according to protocol ${ }^{8}$. Total mastectomy was performed in the oncology department at Ziauddin Hospital as part of palliative treatment due to the gangrene and myiasis. She was also started on radiotherapy and chemotherapy for ductal carcinoma; the chemotherapeutic regimen included capecitabine $1200 \mathrm{mg} / \mathrm{m}^{2}$ twice a day for 21 days with repeat cycles after every 21 days for 6 weeks. Total radiation dose was 5000 cGy delivered in 25 fractions 5 days

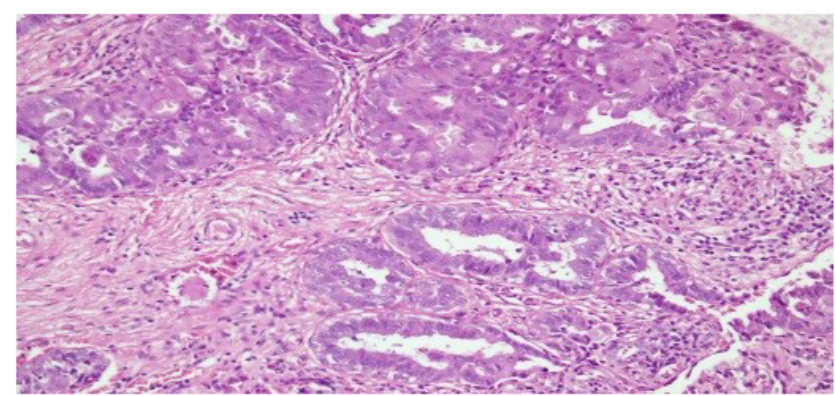

Figure 1. Histological resection of invasive ductal carcinoma.

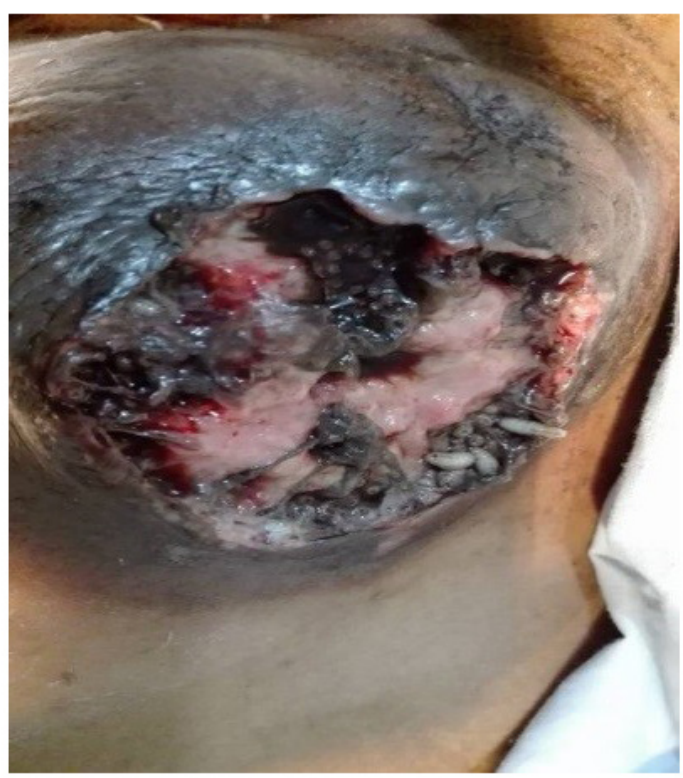

Figure 2. Photograph showing a well demarcated ulcer with myiasis.

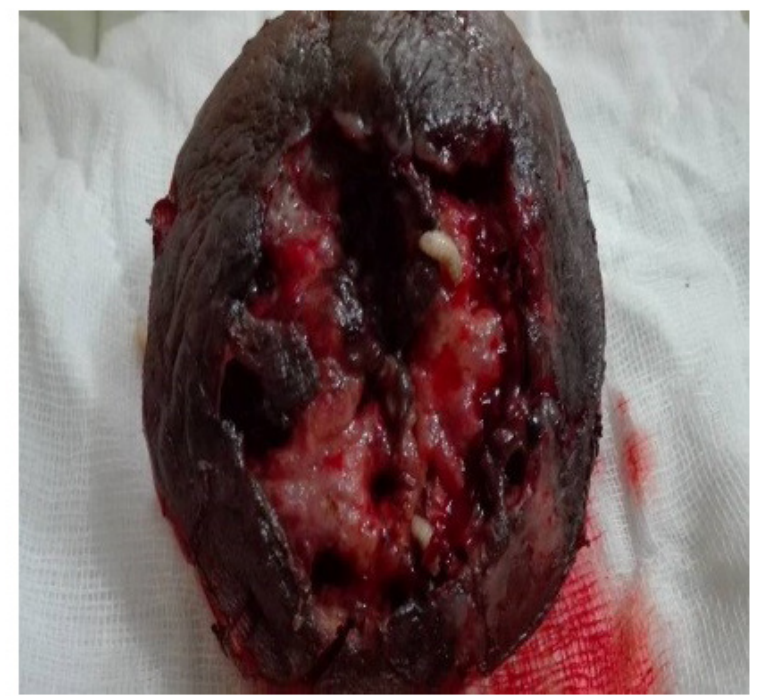

Figure 3. Photograph showing a resected ulcer with numerous Chrysomya bezziana larvae.

a week for 6 weeks. Two months after ceasing her treatment with ivermectin and amoxicillin, breast tissue was healed and surrounded by scarring.

\section{Discussion}

Cutaneous myiasis is a rare entity. It is an infestation of human skin with maggots of flies which feed on host tissues. There are 
two classifications of myiasis, anatomical and ecological. The first description of myiasis was given by Hope in 1840. Since then many cases of myiasis affecting different human organs have been described ${ }^{2,3,6,7}$. Francesconi ${ }^{4}$ used an anatomical classification of myiasis, in which it is grouped into sanguinivorous or bloodsucking, cavitary, wound, cutaneous, furuncular and migratory myiasis.

Flies lay eggs which hatch in a humid and warm environment, and larvae can get access directly to skin from wet clothes, buds or insects. Cutaneous myiasis is very uncommon; the majority of cases are caused by human botfly (Dermatobia hominis) ${ }^{5,8}$. Cutaneous myiasis is presented as a slow developing ulcer or boils. Some of the physical presentations of mastitis are similar to those of carcinoma of the breast $\mathrm{t}^{10}$. It is important to note that an affected breast with myiasis, which appears like fungating mass with an ulcer, can be sometimes misdiagnosed and is confused with tuberculosis, mycosis, actinomycosis, furunculosis, chronic breast abscess, fungating malignancies, periductal mastitis, inflammatory carcinoma of the breast and cellulitis ${ }^{10,11}$. Therefore, it is very important to keep this rare but possible disease in the differentials when diagnosing the condition.

Sample larvae should be promptly preserved after removal in order to maintain their identity, because subsequent treatment is based on the type of the organism identified. Various techniques are available to remove larvae without affecting their shape and structure $^{12,13}$. Risk factors should also be kept in mind, such as living in endemic areas, the characteristic intense itching of the affected breast, offending maggots (seen via a hand magnifying glass) are invaluable aids to the diagnosis and treatment. Poor personal hygiene is an important cause of myiasis;. it can be prevented by proper sanitation, good personal hygiene, spraying insecticides for flies and removal of garbage from nearby streets. Clothes should be worn after washing, drying in sunlight and ironing in order to prevent myiasis ${ }^{14}$.

After the treatment of myiasis, any remaining ulcer should be biopsied in order to rule out any malignancy, as in our case, cutaneous (breast) myiasis simultaneously occurred with invasive ductal carcinoma (Figure 2) and after surgical removal (Figure 3) was confirmed with a biopsy (Figure 1). Invasive ductal carcinoma is the most common type of breast cancer, making up nearly $70-80 \%$ of all breast cancer cases. Invasive or infiltrative ductal carcinoma is the presence of abnormal cancer cells in the lactiferous ducts that have spread into other parts of the breast tissue. It can also metastasize to other parts of the body. Histological examination of breast cancer is mandatory to confirm the diagnosis and to establish different pathological prognostic factors ${ }^{15,16}$.

\section{Conclusion}

Cutaneous myiasis with breast cancer is a rare but possible entity and we should include it in our differentials which is important to avoid any further delay in diagnosis and adequate treatment in the future.

\section{Data availability}

All data underlying the results are available as part of the article and no additional source data are required.

\section{Consent}

Written informed consent for publication of clinical details and clinical images was obtained from the patient.

\section{Grant information}

The author(s) declared that no grants were involved in funding this work.
1. Ellis IO, Elston CW: Tumors of the breast. In: Fletcher CDM. (Ed.): Diagnostic Histopathology of Tumors. Churchill Livingstone, London, 1995.

2. Hope FW: On insects and their larvae occasionally found in the human body. Trans $R$ Soc Entomol. 1840; 2: 256-271. Reference Source

3. Erfan F: Gingival myiasis caused by Diptera (Sarcophaga). Oral Surg Oral Med Oral Pathol. 1980; 49(2): 148-150.

PubMed Abstract | Publisher Full Text

4. Edwards KM, Meredith TA, Hagler WS, et al:: Ophthalmomyiasis interna causing visual loss. Am J Ophthalmol. 1984; 97(5): 605-610. PubMed Abstract | Publisher Full Text

5. Ferrar P: A guide to the breeding habits and immature stages of Diptera Cyclorrhapha. Entomonograph. 1987; 8: 907.

Reference Source

6. Rudan N, Fajdi J, Stanec Z: Kirurgijadojke. Globus, Zagreb, 1998

7. Samija M, Krajina Z, Puru[I] A: Radioterapija. Nakladnizavod Globus, Zagreb, 1996.

8. Francesconi F, Lupi O: Myiasis. Clin Microbiol Rev. 2012; 25(1): 79-105. PubMed Abstract | Publisher Full Text | Free Full Text

9. Jiang C: A collective analysis on $\mathbf{5 4}$ cases of human myiasis in China from 1995-2001. Chin Med J (Engl). 2002; 115(10): 1445-1447. PubMed Abstract
10. de Barros N, D'Avila MS, de Pace Bauab S, et al:: Cutaneous myiasis of the breast: mammographic and US features-report of five cases. Radiology. 2001 ; 218(2): 517-520.

PubMed Abstract | Publisher Full Text

11. Facina G, Nazario ACP, Kemp C, et al.: Myiasis by Dermatobia hominis mimicking periductal mastitis. Rev Bras Mastol. 1999; 9: 84-85.

12. Kahn DG: Myiasis secondary to Sermatobia hominis (human botfly) presenting as a long-standing breast mass. Arch Pathol Lab Med. 1999; 123(9): 829-831. PubMed Abstract

13. Ugwu BT, Nwadiaro PO: Cordylobia anthropophaga mastitis mimicking breast cancer: case report. East Afr Med J. 1999; 76(2): 115-6. PubMed Abstract

14. Kwong A, Yiu WK, Chow LW, et al:: Chrysomya bezziana: a rare infestation of the breast. Breast J. 2007; 13(3): 297-301. PubMed Abstract| Publisher Full Text

15. Olumide YM: Cutaneous myiasis: a simple and effective technique for extraction of Dermatobia hominis larvae. Int $J$ dermatol. 1994; 33(2): 148-9. PubMed Abstract | Publisher Full Text

16. Boggild AK, Keystone JS, Kain KC: Furuncular myiasis: a simple and rapid method for extraction of intact Dermatobia hominis larvae. Clin Infect Dis. 2002; 35(3): 336-8.

PubMed Abstract | Publisher Full Text 


\section{Open Peer Review}

\section{Current Peer Review Status:}

\section{Version 1}

Reviewer Report 26 January 2021

https://doi.org/10.5256/f1000research.20878.r77491

(C) 2021 Liu Y. This is an open access peer review report distributed under the terms of the Creative Commons Attribution License, which permits unrestricted use, distribution, and reproduction in any medium, provided the original work is properly cited.

\section{Yunjiang Liu}

Department of Breast Center, Fourth Hospital of Hebei Medical University, Shijiazhuang, Hebei, China

The authors presented a rare breast invasive ductal carcinoma complicated with cutanous Myiasis.

Can the authors provide more detail about physical examination and diagnostic tests of breast cancer? For example: did the authors performed CT scanning of liver, lung, bone and brain? They should present the disease stage of the case.

Did they finish the immunohistochemistry staining of breast cancer, including hormone receptor (ER, PR) and cerbB-2? It will be useful for other practitioners.

I'd like to remind the importance of breast cancer screening in developing countries.

Is the background of the case's history and progression described in sufficient detail? Yes

Are enough details provided of any physical examination and diagnostic tests, treatment given and outcomes?

Partly

Is sufficient discussion included of the importance of the findings and their relevance to future understanding of disease processes, diagnosis or treatment?

Yes

Is the case presented with sufficient detail to be useful for other practitioners? Partly

Competing Interests: No competing interests were disclosed. 
Reviewer Expertise: breast cancer

I confirm that I have read this submission and believe that I have an appropriate level of expertise to confirm that it is of an acceptable scientific standard.

Reviewer Report 18 November 2019

https://doi.org/10.5256/f1000research.20878.r56440

(C) 2019 Veraldi S. This is an open access peer review report distributed under the terms of the Creative Commons Attribution License, which permits unrestricted use, distribution, and reproduction in any medium, provided the original work is properly cited.

\section{Stefano Veraldi}

Department of Pathophysiology and Transplantation, University of Milan, Milan, Italy

The authors present an interesting case of ulcerative breast carcinoma with Chrysomya bezziana infestation.

It is necessary to explain the reasons for which ivermectin was used. In addition: why this dosage and duration?

It is also necessary to add that Cordylobia anthropophaga is typical of Western Africa, Cordylobia rodhaini of Eastern Africa and Dermatologia hominis of Latin America.

A language edit is required.

Is the background of the case's history and progression described in sufficient detail? Yes

Are enough details provided of any physical examination and diagnostic tests, treatment given and outcomes?

Yes

Is sufficient discussion included of the importance of the findings and their relevance to future understanding of disease processes, diagnosis or treatment?

Yes

Is the case presented with sufficient detail to be useful for other practitioners? Yes

Competing Interests: No competing interests were disclosed.

Reviewer Expertise: Infectious and parasitic diseaes of the skin. Tropical dermatology.

I confirm that I have read this submission and believe that I have an appropriate level of 
expertise to confirm that it is of an acceptable scientific standard, however I have significant reservations, as outlined above.

The benefits of publishing with F1000Research:

- Your article is published within days, with no editorial bias

- You can publish traditional articles, null/negative results, case reports, data notes and more

- The peer review process is transparent and collaborative

- Your article is indexed in PubMed after passing peer review

- Dedicated customer support at every stage

For pre-submission enquiries, contact research@f1000.com 